\title{
Hepatoprotective Natural Products
}

\author{
Omayma A. Eldahshan ${ }^{*}$
}

Pharmacognosy Department, Faculty of Pharmacy, Ain Shams University, Cairo, Egypt

\begin{abstract}
Egypt holds a unique position in the epidemiology of liver diseases and cancer. We, here, shed the light on some important plant extracts and pure compounds that could be used as a new building unit for treatment of liver diseases.
\end{abstract}

Keywords: Hepatoprotective; Natural Products.

*Correspondence | Omayma A. Eldahshan; Pharmacognosy Department, Faculty of Pharmacy, Ain Shams University, African union organization street Abassia, 11566, Cairo, Egypt. Email: oeldahshan@pharma.asu.edu.eg

Citation | Omayma A. Eldahshan. 2017. Hepatoprotective Natural Products. Arch Pharm Sci ASU 1(2): $46-47$

DOI: $10.21608 /$ aps.2017.11027

Online ISSN: 2356-8380. Print ISSN: 2356-8399.

Received 19 August 2017. Accepted 19 October 2017.

Copyright: ${ }^{\circledR} 2017$ Eldahshan. This is an open-access article licensed under a Creative Commons Attribution 4.0 International License (CC BY 4.0), which permits unrestricted use, distribution, and reproduction in any medium, provided the original author(s) and source are credited.

Published by: Ain Shams University, Faculty of Pharmacy.

\section{INTRODUCTION}

Hepatotoxins as chemicals, pharmaceutical drugs, alcohols, pollutants, hepatitis viral infection or even some medicinal plants are responsible for hepatotoxicity [1]. Annually, about more than two million people in the world die from liver-related disorders [2]. Nature is fighting liver disorders by their plant extracts and/or phytochemicals. This mini-review displays the potentials of some extracts as well as pure constituents as hepatoprotector.

\section{Acrocarpus fraxinifolius}

Alcoholic extract of Acrocarpus fraxinifolius (Fabaceae) could ameliorate hepatic injuries induced by $\gamma$-irradiation and $\mathrm{CCl} 4$ in rats suggesting potent hepatoprotective activity. In vivo, it reduced interleukin-6, TNF-a, nitric oxide, malondialdehyde, and DNA fragmentation and caspase-3 activity. It downregulated its m-RNA level and decreased proapoptotic protein Bax expression. In addition, the extract enhanced superoxide dismutase, glutathione peroxidase, catalase activities. It reduced glutathione concentrations and up-regulated the expression of antiapoptotic Bcl-2 [3]. Its hexane extract significantly alleviated the liver relative weight and biomarkers (serum aspartate aminotransferase, alanine aminotransferase, and alkaline phosphatase), lipid and bilirubin profiles and hepatic lipid peroxidation. It also increased body weight, serum protein profile and hepatic antioxidant capacity in paracetamol-induced hepatotoxicity in rats [4].

\section{Lygodium microphyllum}

Lygodium microphyllum (Cav.) R.Br. (Lygodiaceae) leaves aqueous extract could exert hepatoprotection that could be attributed to its antioxidative effects through protection of ultrastructural organelles. The extract was able to prevent the increase in levels of serum ALT, AST and hepatic malondialdehyde formation in a dosedependent manner. Immunohistochemical results proved the suppression of oxidative stress markers as 4-hydroxynonenal, 8- 
hydroxydeoxyguanosine, and pro-inflammatory cytokines as TNF-a, Il-6, PG-E 2 [5].

\section{Panax quinquefolius}

Panax quinquefolius saponin exerts a protective effect against acetaminophen-induced hepatic injury because of its antioxidant, antiapoptotic, and anti-inflammatory activities. Pretreatment with Panax quinquefolius saponin (ginsenoside) significantly decreased serum ALT, AST, TNF- $\alpha$, and IL- $1 \beta$ levels in a dosedependent manner as compared to the acetaminophen administration. In addition, it decreased hepatic malondialdehyde contents and 4-hydroxynonenal expression and restored reduced glutathione content and superoxide dismutase activity in livers of mice. It inhibited the overexpression of cyclooxygenase- 2 and inducible nitric oxide synthase in the liver cells. The extract pretreatment inhibited the activation of apoptotic signaling pathways (through the increase of Bcl-2 and decrease of Bax and caspase-3 protein expression levels) [6].

\section{Apigenin}

Apigenin is found in many medicinal plants. After its oral administration, the levels of serum ALT and AST were decreased. Apigenin pretreatment increased the levels of the following; hepatic nuclear factor, erythroid 2related factor 2, superoxide dismutase, catalase, glutathione S-transferase, and glutathione reductase activities. At the same time, it decreased the levels of tumor necrosis factor- $\alpha$ and hepatic nuclear factor- $\kappa \mathrm{B}$ protein expression. These findings demonstrated that apigenin could prevent the D-GalN/LPS-induced liver injury in mice, and its mechanisms might be associated with the increments of Nrf-2-mediated antioxidative enzymes and modulation of PPAR $\gamma / \mathrm{NF}-\kappa \mathrm{B}-\mathrm{mediated}$ inflammation [7].

\section{Conclusion}

This mini-article provided evidence that nature is full of miracles that produce many potential hepatoprotectors. However, they must be evaluated later in pre-clinical and clinical assays to determine their safety and their preventive capacity to build a new block in liver drug discovery.

\section{References}

1. Paraskevi A, Ronald A (2006). Hepatocellular carcinoma pathogenesis: from genes to environment. Nat Rev Cancer. 6:1-14.

2. Bukhsh E, Malik SA, Ahmad SS, Erum S (2014). Hepatoprotective and hepatocurative properties of alcoholic extract of Carthamus oxyacantha seeds. African J Plant Sci. 8:34-41.

3. El-Nashar HAS, Eldahshan OA, Elshawi OE, Singab ANB (2017). Phytochemical Investigation, Antitumor Activity, and Hepatoprotective Effects of Acrocarpus fraxinifolius Leaf Extract. Drug Dev Res 78(5):210-226

4. Abd El-Ghaffar EA, El-Nashar HA, Eldahshan OA, Singab AN (2017). GC-MS analysis and hepatoprotective activity of the n-hexane extract of Acrocarpus fraxinifolius leaves against paracetamol-induced hepatotoxicity in male albino rats. Pharm Biol. 55 (1): 441-449.

5. Gnanaraj C, Shah MD, Song TT, Iqbal M (2017). Hepatoprotective mechanism of Lygodium microphyllum (Cav.) R.Br. through ultrastructural signaling prevention against carbon tetrachloride (CCl4)-mediated oxidative stress. Biomed Pharmacother. 92:1010-1022.

6. Xu XY, Hu JN, Liu Z, Zhang R, He YF, Hou W, Wang ZQ, Yang G, Li W (2017). Saponins (Ginsenosides) from the Leaves of Panax quinquefolius Ameliorated AcetaminophenInduced Hepatotoxicity in Mice. J Agric Food Chem. 65(18):3684-3692

7. Zhou RJ, Ye H, Wang F, Wang JL, Xie ML (2017). Apigenin inhibits d-galactosamine/LPSinduced liver injury through upregulation of hepatic Nrf-2 and PPAR $\gamma$ expressions in mice. Biochem Biophys Res Commun. 4;493(1):6256302. 